\title{
Traditional sour cassava starch obtained with alterations in the solar drying stage
}

\author{
Daniele Iensen de OLIVEIRA ${ }^{1}$, Letícia DEMOGALSKI ${ }^{1}$, Ariangelo Hauer DIAS ${ }^{2}$, Luiz Américo Alves PEREIRA ${ }^{3}$, \\ Aline ALBERTI ${ }^{1}$, Paulo Ricardo LOS ${ }^{1}$, Ivo Mottin DEMIATE ${ }^{1 \star}$ (D)
}

\begin{abstract}
After natural fermentation and solar drying, sour cassava starch acquires expansion property. Traditionally, solar drying occurs without protection, and consequently physical contamination can arise. Thus, the aim of this study was to produce sour cassava starch using a low-cost solar dryer to prevent contamination, whilst retaining the expansion property. The samples were characterized in relation to chemical composition, microscopy and physical contaminants, as well as expansion, thermal, pasting, structural and technological properties. In addition, biscuits were prepared and compared with commercial samples. The solar dryer provided faster drying and lower moisture levels than the control. The specific volumes of the sun-dried products were similar to the control, with minimized contamination. The granules of the starches showed slight erosion on their surface, which was probably due to amylolytic enzymes. X-ray diffraction showed a typical A-type pattern. DSC analysis resulted in higher gelatinization temperatures and enthalpy changes for the sour cassava starch. The pasting properties showed a reduction in the viscosity peak at neutral pH. Although the cassava starch biscuits made with sour cassava starch dried in the solar dryer presented lower expansion levels in relation to the other biscuits produced with commercial sour cassava starch, they had desirable sensory characteristics.
\end{abstract}

Keywords: cassava starch; expansion property; Manihot esculenta Crantz; natural fermentation.

Practical Application: Using solar drying to produce sour cassava starch provided a product with acceptable hygienic quality and guaranteed expansion property for use in expanded baked products.

\section{Introduction}

Sour cassava starch (polvilho azedo) is an indigenous Brazilian food ingredient that is produced by natural fermentation and sun-drying of cassava starch (Aquino et al., 2015). It is a traditional and valued ingredient for its high sensory quality (expansion at baking, taste/odor), but the artisanal production without quality control is prompting to market change, which prefer cheaper chemically modified substitutes (Aquino et al., 2016).

Lactic acid bacteria (LAB) are the most reported microrganisms during the spontaneous fermentation of cassava starch; yeasts and molds are also reported as being present but in lower numbers. Organic acids (lactic, acetic, propionic and butyric) are synthesized during fermentation and, together with amylolytic enzymes and solar radiation, act on the starch granules, resulting in new physicochemical properties, including the desirable and unique property of baking expansion (Aquino et al., 2015; Demiate et al., 2000; Garcia et al., 2016; Qi et al., 2020).

Natural drying is of great interest as it is a promising technique to use solar energy, which is a renewable and clean source of energy (Eltawil et al., 2018; García-Valladares et al., 2020). However, sun-drying fermented cassava starch is performed without any protection against physical contamination, which compromises its quality. Numerous quality concerns related to physical contamination (insect fragments, soil particles and other foreign materials) have been reported as affecting consumer acceptance of this type of starch. Standardization is urgently required in order to increase the market for sour cassava starch (Aquino et al., 2016).

Developing a controlled process, including a low-cost solar dryer that is easy to assemble and manufacture, can prevent undesirable physical contamination (Almeida et al., 2016; Sharma et al., 2009) and improve the drying efficiency (Eltawil et al., 2018). Thus, this study proposes a hygienic process to produce high-quality, sun-dried traditional sour cassava starch that is free of physical contaminants and has high expansion levels when baked.

\section{Materials and methods}

\subsection{Sample preparation, chemical composition and physical contamination}

The development of the solar dryer included the testing of polymeric materials designed to be transparent to ultraviolet radiation. A UV-visible spectrophotometer (Varian, Cary 
50, Palo Alto, USA) was used to check the transmittance of the following main potential materials: acrylic plate $(3.0 \mathrm{~mm}$ thickness); common flat glass (2.6 mm thick); polycarbonate plate $(2.0 \mathrm{~mm}$ thick); polyethylene film (0.04 mm thick) and PVC film (0.008 mm thick). A quartz cuvette (2.52 mm thick) was used as reference because it presents high transmittance through the UV region.

The solar dryer was built with $6 \mathrm{~mm}$-thick wood plates, including a main structure and a solar radiation collector. The upper base of the solar collector was covered with aluminum cans that were dented and painted with black paint to increase the internal temperature of the dryer (Milczarek et al., 2016). PVC film ( $8 \mu \mathrm{m}$ thick) was chosen because it was transparent in relation to UV-radiation, and it was used to cover the dryer. The model and the specifications of the equipment are shown in Figure 1.

Natural fermentation was performed using $90 \%\left(\mathrm{~g} \mathrm{~g}^{-1}\right)$ of native cassava starch and $10 \%\left(\mathrm{~g} \mathrm{~g}^{-1}\right)$ of commercial sour cassava starch as starter (1800 g and $200 \mathrm{~g}$, respectively) (Aquino et al., 2016). For the fermentation process the native cassava starch and starter sour starch were homogenized/suspended in tap water in a 1:2 starch: water $\left(\mathrm{g} \mathrm{mL}^{-1}\right)$ ratio. Fermentation occurred at rest at $20^{\circ} \mathrm{C}$ (Mestres \& Rouau, 1997) and was continuously monitored by measuring temperatures from the supernatant water, $\mathrm{pH}$ values and total titratable acidity (Instituto Adolfo Lutz, 2008). All the determinations were performed in triplicate.

When fermentation reached the desired acidity $(5.0 \mathrm{~mL}$ of $1 \mathrm{~mol}$ $\mathrm{L}^{-1} 100 \mathrm{~g}^{-1} \mathrm{NaOH}$ solution) the supernatant water was eliminated and the moist starch was distributed on baking trays (approximately $500 \mathrm{~g}$ and $5 \mathrm{~mm}$ height), in a proportion of 1:2.25 moist starch mass: tray area $\left(\mathrm{g} \mathrm{cm}^{-2}\right)$. The fermented starch was divided into three parts for the drying process. One part was dried in the solar dryer (SD), another part was dried under the sun without any protection against physical contamination (USD), and the final part was oven-dried at $40^{\circ} \mathrm{C} / 24 \mathrm{~h}(\mathrm{OD})$. All the drying tests were performed in duplicate, using the same amounts of moist starch evenly distributed in the drying trays. The maximum moisture of $18 \%$ was considered to finish the drying (Brasil, 2005).

A programming system was developed using Arduino software (IDE, downloaded from Arduino (2020)) to control the drying conditions inside the dryer (UV-radiation intensity, relative humidity and temperature). For this, we used ML8511-UV (Lapis Semiconductor, Yokohama, Japan) and DHT22 (Aosong Electronics, Guangzhou, China) sensors, which were connected to an Arduino Duemilanove board/microcontroller (Arduino, Monza, Italy).

The chemical composition of the fermented starch was assessed by determining moisture, protein, lipids, ash and total carbohydrates (Instituto Adolfo Lutz, 2008).

The search for physical contamination was performed according to Demiate et al. (1997a) with slight modification. Briefly, the samples were hydrolyzed with $\mathrm{HCl}$ solution, cooled to room temperature and neutralized. The solution was filtered on a checkered filter paper in a Büchner funnel coupled to a vacuum pump (Biomec, ECO-740, Araucária, PR, Brasil). Squared filter paper was examined by optic microscopy after filtration: $40 \times$ and $100 \times$ magnifications were used to quantify foreign material.

\subsection{Starch granule morphology}

The starch granule morphology was examined by scanning electron microscopy (SEM) (Tescan, Vega 3, Brno, Czech Republic) with $25 \mathrm{kV}$ acceleration tension and 3,500× magnification (Pereira et al., 2016).
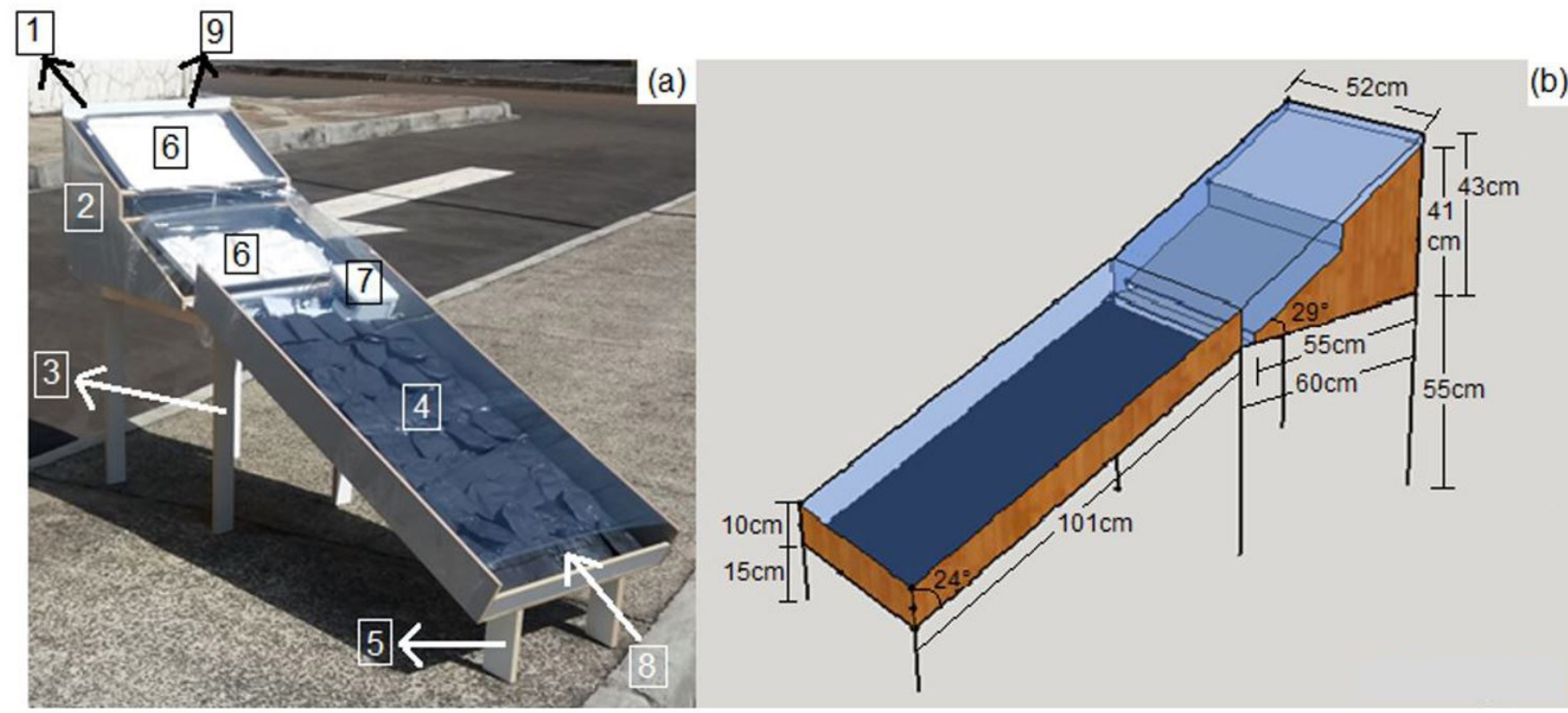

Figure 1. Model of solar dryer for sour cassava starch. Note: real model (a) and 3D model (b), developed using SketchUp software (version Make 2017) with the following dimensions: 1 : main structure door; 2 : main structure side wall; 3 : main structure supporting feet; 4: solar collector; 5: solar collector supporting feet; 6: drying trays with dimensions of 47.5 x 32.0 x $5.5 \mathrm{~cm}$ (length x width x height); 7: sensor system; 8: natural air intake; and 9: damp air outlet. 


\subsection{Organic acid profile and total acidity}

The organic acid profile of the sour cassava starch was analyzed by high-performance liquid chromatography (Shimadzu Corporation, Kyoto, Japan) coupled to a diode array detector (SPD-M20A) working in the 190-240 $\mathrm{nm}$ range. The samples were prepared according to Demiate et al. (1999) and compared with external standards (lactic, acetic, propionic and butyric acid). The mobile phase used was $0.005 \mathrm{~mol} \mathrm{~L}^{-1}$ sulfuric acid and the flow rate was set at $0.5 \mathrm{~mL} \mathrm{~min}^{-1}$. Total titratable acidity was determined conventionally (Instituto Adolfo Lutz, 2008).

\subsection{Expansion property}

Expansion at baking was determined by measuring the volume of the biscuits by the displacement of canary seeds. The specific volume was expressed as $\mathrm{mL} \mathrm{g}^{-1}$ (Demiate et al., 2000; Maeda \& Cereda, 2001).

\subsection{Amylose content}

Iodine affinity (IA) was determined for the starch samples, which were previously defatted, using a potentiometric auto titrator (Metrohm, 848 Titrino Plus, Herisau, Switzerland) (Schoch, 1964). The amylose level was calculated by dividing the iodine affinity (IA) of the starch by the IA of amylose (20\%).

\subsection{X-ray diffraction}

The X-ray diffractograms were collected using an X-ray diffractometer (Rigaku, Ultima IV, Tokyo, Japan), $\mathrm{Cu}_{\mathrm{Ka}}$ radiation $(\lambda=1.544 \AA)$. The relative crystallinity index was calculated as the ratio between the area of the crystalline region and the total area covered by the curve (Bhattacharjya et al., 2015; Nara \& Komiya, 1983).

\subsection{Pasting properties}

The pasting properties were analyzed using a Rapid Visco Analyzer (Newport Scientific, RVA-4 Series, Warriewood, Australia). Suspensions at $8 \%\left(\mathrm{~g} \mathrm{~g}^{-1}\right)$ of starch samples were prepared with water or buffer solutions and the total amount of suspension was always $28 \mathrm{~g}$. Distilled water, $\mathrm{pH} 4.0$ and $\mathrm{pH} 6.0$ buffer solutions $\left(0.1 \mathrm{~mol} \mathrm{~L}^{-1}\right.$ sodium acetate), were the solvents for the analyses. The Standard Analysis 2 (STD2) profile from Thermochline for Windows software was used (Demiate et al., 2016).

\subsection{Thermal properties}

The thermal properties were analyzed using a differential scanning calorimeter (DSC) (TA Instruments, TA Q200, New Castle, USA), calibrated with $99 \%$ pure indium (melting point $=156.6^{\circ} \mathrm{C} ; \Delta \mathrm{H}=28.56 \mathrm{~J} \mathrm{~g}^{-1}$ ) (Demiate et al., 2005).

\subsection{Sensory analysis}

Five formulations of biscuits were prepared, considering five different sour cassava starches (Aplevicz \& Demiate, 2007). The sour cassava starch that was sun-dried inside the developed dryer (sample BSD) and four commercial sour cassava starches (C1, C2, C3 and C4) were used for this sensory analysis.

The selected form of sensory analysis was ranking descriptive analysis (RDA) (Richter et al., 2010), which involved the pre-selection and training of panels to perform the RDA. The procedures and all the descriptions were presented to, and approved by, the Ethical Committee of Research with Humans of the State University of Ponta Grossa (Protocol No. 2.436.095). After the panel's consent was granted, the pre-selection consisted of a single triangular test (Associação Brasileira de Normas Técnicas, 1993), evaluating the sensory difference between two samples made from commercial sour cassava starch. Wald's sequential method was used as the criterion for selecting the panels (Shirose \& Mori, 1984). The development of the descriptive terminology was performed by the 13 pre-selected panels by using the Network Method (Moskowitz, 1983).

The panels performed RDA three times with intervals between the tests to avoid sensory fatigue. The panels received the samples in identified disposable cups that were codified with aleatory three-digits numbers, together with a cup of water and a form with the descriptive terms. The five samples were presented to the panels at the same time; they were ordered considering the intensity of each of the attributes that were chosen and defined by the group, according to the evaluation form.

The results were analyzed by generalized procrustes analysis (GPA) using Idiogrid, version 2.4, software (Oklahoma State University, Stillwater, USA) to compare the configuration of the samples and to verify the efficiency and consensus of the group. In order to analyze the intensity of the differences between the attributes, the existence of significant differences between the samples was taken into consideration (Friedman test), with five samples and 13 panels (Christensen et al., 2006).

\subsection{Statistical analysis}

All the analyses were performed in triplicate and the results were expressed as mean \pm SD. The homogeneity of variance was checked by the Brown-Forsythe test $(\mathrm{p}>0.05)$ and significant differences were analyzed by one-way ANOVA. When necessary, the Fisher test was used to compare averages $(\mathrm{p}<0.05)$. The statistical analyses were performed using Statistica software, version 13.3 (TIBCO, Palo Alto, USA).

\section{Results and discussion}

\subsection{Natural fermentation, solar drying, chemical composition and physical contamination}

The fermentation process lasted 20 days and was finished when the titratable acidity corresponded to $5.83 \mathrm{~mL}$ of $1 \mathrm{~mol} \mathrm{~L}^{-1}$ $\mathrm{NaOH} 100 \mathrm{~g} \mathrm{~g}^{-1}$. The temperature of the room during fermentation was $22.03 \pm 0.85^{\circ} \mathrm{C}$, with the supernatant temperature being $22.18 \pm 0.78^{\circ} \mathrm{C}$. After the fourth day of fermentation there was a rapid increase in $\mathrm{pH}$ and a decrease in acidity, possibly because of organic acid consumption by fungi. After the eighth day, the development of mold decreased and acidity increased, with a 
consequent decrease in $\mathrm{pH}$. Similar behavior was previously reported (Díaz et al., 2018).

The drying process occurred in only one day, for six hours inside the dryer, and for seven hours directly, unprotected under the sun. The solar dryer accelerated the drying process, reducing the total drying period and resulting in a lower final moisture content. The temperature and relative humidity profile from inside the solar dryer is shown in the Figure 2.

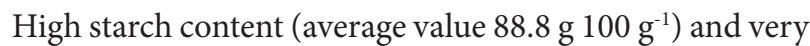
low concentrations of other components $(10.93,0.14,0.06$, and

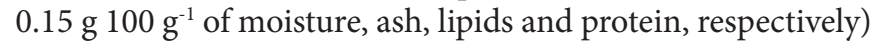
were found both for the native and fermented starches, proving a high level of purity.

Brazilian legislation does not cover the presence of foreign material in cassava sour starch. Therefore, comparisons were performed by considering commercial samples described in the literature (Demiate et al., 1997a, b, 1998). The samples of native starch, as well as the oven-dried sour cassava starch, were free from physical contamination (Table 1). However, the other samples were contaminated at different levels by insect fragments and soil/sand particles. The presence of insects (adults, larvae and pupae) was observed for the sample that was dried unprotected under the sun and also for the commercial sour cassava starch. These insects are attracted by the white color of

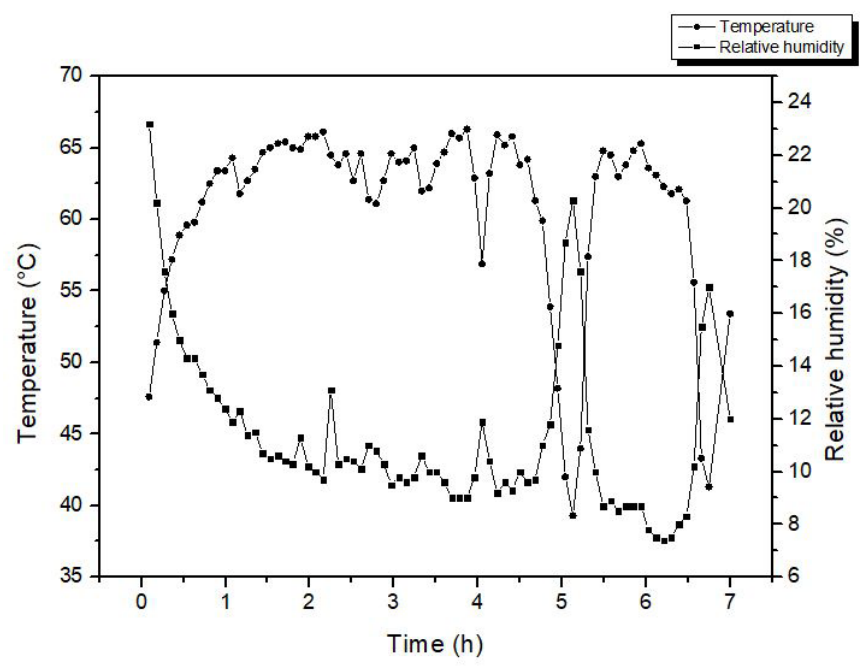

Figure 2. Temperature and relative humidity profile. the starch exposed to sunlight. The developed solar dryer was effective in minimizing this physical contamination and presented only very little contamination, which was due to unprotected air openings. That issue could have been overcome by the use of appropriate screens.

\subsection{Starch granule morphology}

The granules from both the native and fermented cassava starches showed spherical and truncated shapes (figures not shown). Some surface erosion could be seen on the granules of the fermented starch, probably due to the action of amylolytic enzymes on the amorphous fraction of the starch, and also because of lactic acid bacteria activity (Alonso-Gomez et al., 2016). The same behavior has been previously described by other authors (Pereira et al., 2016; Sumardiono et al., 2018).

\subsection{Organic acid profile and total acidity}

The concentrations of d-lactic, l-lactic, acetic, propionic and butyric acids, and the total titratable acidity of the starch samples, are shown in Table 2. The higher concentration of butyric acid could be explained by elevated temperatures during the fermentation process. Previous studies have shown that at lower temperatures fermentation is slow and lactic acid bacteria predominate, most frequently Lactobacillus plantarum; however, at higher temperatures there is rapid butyric fermentation and Clostridium butyricum is more relevant (Mestres et al., 2000; Silveira et al., 2003). There was no difference between the titratable acidity values of the samples. The total organic acid concentrations were consistent, although numerical difference occurred, which could be explained by the different techniques that were used to evaluate those parameters.

\subsection{Expansion property}

The expansion property was measured by the specific volume of the biscuits. The lowest value was found for the native cassava starch $(\mathrm{N}), 2.86 \pm 0.05 \mathrm{~mL} \mathrm{~g}^{-1}$, which was significantly different from the values for the SD and USD samples, which did not differ between themselves, $4.23 \pm 0.31$ and $4.61 \pm 0.48 \mathrm{~mL} \mathrm{~g}^{-1}$, respectively. Previous studies have reported that of the organic acids formed during the fermentation of sour cassava starch, lactic acid is the main acid responsible for the expansion property (Cereda \& Bonassi, 1985; Oliveira, 2016). However, in the present

Table 1. Physical contamination in starches.

\begin{tabular}{ccccc}
\hline Starches $^{1}$ & $\begin{array}{c}\text { Insect fragments } \\
\left(\mathrm{n}^{\mathrm{o}} 10 \mathrm{~g}^{-1}\right)\end{array}$ & $\begin{array}{c}\text { Whole insects } \\
\left(\mathrm{n}^{\mathrm{o}} 10 \mathrm{~g}^{-1}\right)\end{array}$ & $\begin{array}{c}\text { Larvae and/or pupae } \\
\left(\mathrm{n}^{\mathrm{o}} 10 \mathrm{~g}^{-1}\right)\end{array}$ & - \\
\hline $\mathrm{N}$ & - & - & - & Soil particles $\left(\mathrm{n}^{\mathrm{o}} 10 \mathrm{~g}^{-1}\right)$ \\
OD & - & - & - & - \\
SD & $1.67^{\mathrm{bc}} \pm 0.58$ & - & $1.00 \pm 1.00$ & $5.67^{\mathrm{b}} \pm 2.08$ \\
USD & $3.33^{\mathrm{b}} \pm 2.08$ & $0.33 \pm 0.58$ & $0.33 \pm 0.58$ & $10.33^{\mathrm{ab}} \pm 5.51$ \\
CS & $7.67^{\mathrm{a}} \pm 1.53$ & $0.33 \pm 0.58$ & $11.33^{\mathrm{a}} \pm 2.52$ \\
\hline
\end{tabular}

Values followed by different superscript letters in the same column indicate significant difference at $\mathrm{p}<0.05$ (Fisher); ${ }^{1} \mathrm{~N}$ : native cassava starch; OD, SD and USD: sour cassava starches dried in the oven, in the solar dryer, and under the sun without any protection, respectively; CS: commercial sour cassava starch (starter). 
study lactic acid was found in very limited concentrations, which may be an explanation for the relatively low expansion values.

\subsection{Amylose content}

The amylose content did not differ between the samples, ranging from $25.2 \pm 0.3$ to $26.1 \pm 1.1$, which was in line with previous data (Díaz et al., 2018). Some authors have reported a relationship between amylose content and the expansion of similar baked products. The lower the amylose level, the higher the level of expansion; a fact probably associated with less amylose-lipid complexes (Alvarado et al., 2013). Our results show amylose content a little bit higher than most reported values in the literature, which may explain the limited expansion at baking.

\subsection{X-ray diffraction}

All the samples showed peaks at $15,17,18$ and $23^{\circ}(2 \theta$ angle) (Figure 3), typical of an A-type polymorph. There were no differences between the XRD patterns of the samples, indicating that oxidation was very light and did not cause enough structural changes to be detected by this technique. Oxidation seems to occur preferentially in the amorphous fraction (Beninca et al., 2013; Meng et al., 2018). Relative crystallinity associates with the content of amylose and amylopectin in starch granules. As no differences were observed in the amylose levels of the samples, the relative crystallinity values were also similar.

\subsection{Pasting properties}

The results showed that the $\mathrm{pH}$ values impacted on the pasting properties (Table 3 ). There was a drop in the peak viscosities when the analysis was performed at $\mathrm{pH} 6.0$ for all samples, except the native cassava starch $(\mathrm{N})$. Decreasing viscosity, in line with $\mathrm{pH}$ values close to neutrality, were observed for the sun-dried and oven-dried sour cassava starches, the acidified cassava starch that was sun-dried, and the chemically-oxidized cassava starch. These starches apparently have the same kind of structural modification, i.e. light oxidation. Oxidation can result in the partial degradation of macromolecules, as well as the inclusion of carbonyl and carboxyl groups. Carboxyl groups will present negative charges, depending on the $\mathrm{pH}$, and then the starch polysaccharides will behave as polyelectrolytes (Mestres et al., 2000; Nara \& Komiya, 1983).

The native cassava starch showed the highest peak viscosity, as well as setback value, when compared with the sour cassava starch samples, which was in line with a previous study (Alvarado et al., 2013). This behavior can be explained by the action of amylases and of organic acids derived from fermentation, as well as the tendency of oxidized starches to have conformational alterations (Lawal et al., 2005). The lower setback values for the sour cassava

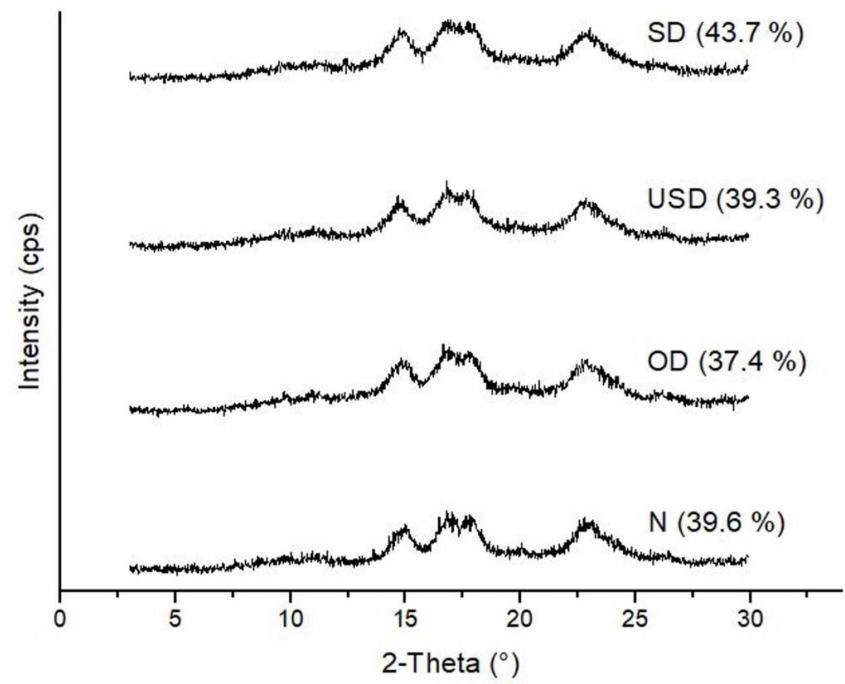

Figure 3. X-ray diffraction patterns and the numbers in parentheses are the percentages of relative crystallinity of starch samples. Note: N: native cassava starch; OD, SD, USD: sour cassava starches dried in the oven, in the solar dryer, and under the sun without any protection, respectively.

Table 2. Concentration of organic acids and \% of total acids and total titratable acidity of starches.

\begin{tabular}{|c|c|c|c|}
\hline Starches ${ }^{1}$ & OD & SD & USD \\
\hline D-lactic acid $\left(\mathrm{mg} \mathrm{kg}^{-1}\right)$ & - & $<$ LOQ & - \\
\hline$\%$ & - & 0.0 & - \\
\hline$\%$ & 0.0 & 0.0 & 0.0 \\
\hline Acetic acid $\left(\mathrm{mg} \mathrm{kg}^{-1}\right)$ & $<$ LOQ & $589^{\mathrm{a}} \pm 1$ & $559^{\mathrm{b}} \pm 3$ \\
\hline Propionic acid $\left(\mathrm{mg} \mathrm{kg}^{-1}\right)$ & $635 \pm 7$ & $<$ LOQ & $<$ LOQ \\
\hline$\%$ & 29.2 & 0.0 & 0.0 \\
\hline Butyric acid $\left(\mathrm{mg} \mathrm{kg}^{-1}\right)$ & $1,536^{\mathrm{a}} \pm 36$ & $1,308^{\mathrm{b}} \pm 8$ & $1,245^{\mathrm{c}} \pm 2$ \\
\hline$\%$ & 70.8 & 69.0 & 69.0 \\
\hline
\end{tabular}

Values followed by different superscript letters in the same column indicate significant difference at $\mathrm{p}<0.05$ (Fisher); ${ }^{1} \mathrm{OD}$, SD, USD: sour cassava starches dried in the oven, in the solar dryer, and under the sun without any protection, respectively. 
starch could be related to the presence of bulky carboxyl groups that prevent molecular interactions (Matsuguma et al., 2009). The pasting properties are also affected by amylose, lipids and phosphorus content, and the length distribution of the side chain of amylopectin (Jane et al., 1999).

\subsection{Thermal properties}

As well as having lower setback values, the fermented starches also had the highest values for DSC gelatinization temperatures and enthalpy change when compared with the native starch (Table 4, Figure 4). Because the fermentation process will preferentially partially degrade the amorphous fraction of the starch granules, it can be assumed that these samples will be a little bit more difficult to gelatinize (Alonso-Gomez et al., 2016). In general, the sun dried samples resulted in a greater gelatinization enthalpy than native starch and oven dried sample. This parameter measures the amount of energy required for gelatinization to occur, providing information related to the sample's crystallinity (Vanier et al., 2012).

\subsection{Sensory analysis}

The sensory analysis was carried out by adopting generalized procrustes analysis (GPA). GPA seeks to create a consensus

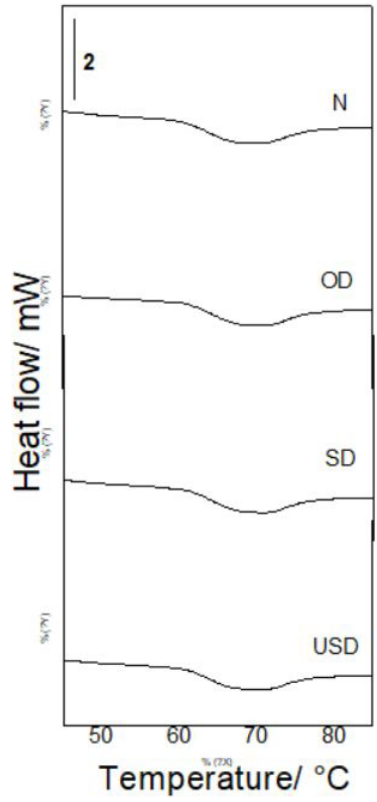

Figure 4. Thermal properties of the starches. Note: N: native cassava starch; OD, SD, USD: sour cassava starches dried in the oven, in the solar dryer, and under the sun without any protection, respectively.

Table 3. Viscoamylographic properties (RVA) of starches in different solvents.

\begin{tabular}{|c|c|c|c|c|c|c|c|}
\hline Starches ${ }^{1}$ & $\begin{array}{l}\text { Peak viscosity } \\
\text { (cP) }\end{array}$ & $\begin{array}{l}\text { Minimum } \\
\text { viscosity } \\
\text { (cP) }\end{array}$ & $\begin{array}{l}\text { Breakdown } \\
\quad(\mathrm{cP})\end{array}$ & $\begin{array}{l}\text { Final viscosity } \\
\text { (cP) }\end{array}$ & $\begin{array}{l}\text { Setback } \\
(\mathrm{cP})\end{array}$ & $\begin{array}{l}\text { Peak time } \\
\quad(\min )\end{array}$ & $\begin{array}{l}\text { Pasting } \\
\text { temperature } \\
\left({ }^{\circ} \mathrm{C}\right)\end{array}$ \\
\hline $\mathrm{N}$ - Water & $1,978 \pm 9$ & $607 \pm 1$ & $1,371 \pm 8$ & $1,149 \pm 2$ & $542 \pm 1$ & $6.1^{c} \pm 0.0$ & $67.3^{c} \pm 0.2$ \\
\hline $\mathrm{N}-\mathrm{pH} 4.0$ buffer & $1,884 \pm 61$ & $605 \pm 57$ & $1,279 \pm 4$ & $1,052 \pm 102$ & $447 \pm 45$ & $6.4^{\mathrm{b}} \pm 0.0$ & $68.6^{\mathrm{b}} \pm 0.2$ \\
\hline $\mathrm{N}$ - pH 6.0 buffer & $1,812 \pm 103$ & $648 \pm 17$ & $1,164 \pm 86$ & $1,125 \pm 78$ & $477 \pm 62$ & $6.7^{\mathrm{a}} \pm 0.0$ & $70.7^{\mathrm{a}} \pm 0.0$ \\
\hline OD - Water & $1,605^{\mathrm{a}} \pm 44$ & $419^{\mathrm{a}} \pm 10$ & $1,186^{\mathrm{a}} \pm 34$ & $755^{a} \pm 13$ & $336 \pm 3$ & $6.0^{\mathrm{b}} \pm 0.0$ & $67.7^{c} \pm 0.2$ \\
\hline OD - pH 6.0 buffer & $1,238^{c} \pm 51$ & $362^{\mathrm{b}} \pm 18$ & $877^{\mathrm{b}} \pm 33$ & $666^{\mathrm{b}} \pm 30$ & $305 \pm 12$ & $6.5^{\mathrm{a}} \pm 0.1$ & $70.7^{\mathrm{a}} \pm 0.0$ \\
\hline SD - Water & $1,613^{\mathrm{a}} \pm 30$ & $474^{\mathrm{a}} \pm 18$ & $1,139^{\mathrm{a}} \pm 13$ & $797^{\mathrm{a}} \pm 39$ & $323^{\mathrm{a}} \pm 21$ & $6.0^{\mathrm{b}} \pm 0.0$ & $67.7^{\mathfrak{c}} \pm 0.2$ \\
\hline SD - pH 4.0 buffer & $1,479^{\mathrm{b}} \pm 52$ & $342^{\mathrm{b}} \pm 19$ & $1,138^{\mathrm{a}} \pm 33$ & $632^{\mathrm{b}} \pm 16$ & $291^{\mathrm{a}} \pm 4$ & $6.1^{\mathrm{b}} \pm 0.1$ & $68.9^{\mathrm{b}} \pm 0.3$ \\
\hline SD - pH 6.0 buffer & $1,178^{c} \pm 15$ & $342^{\mathrm{b}} \pm 11$ & $836^{\mathrm{b}} \pm 4$ & $575^{\mathrm{b}} \pm 6$ & $233^{\mathrm{b}} \pm 6$ & $6.5^{\mathrm{a}} \pm 0.0$ & $71.3^{\mathrm{a}} \pm 0.3$ \\
\hline
\end{tabular}

Values followed by different superscript letters in the same column, for each sample, indicate significant difference at $\mathrm{p}<0.05$ (Fisher); ${ }^{1} \mathrm{~N}$ : native cassava starch; OD, SD, USD: sour cassava starches dried in the oven, in the solar dryer, and under the sun without any protection, respectively.

Table 4. Thermal properties of the starches.

\begin{tabular}{|c|c|c|c|c|c|}
\hline Starches ${ }^{\mathrm{a}}$ & $\mathrm{T}_{0}\left({ }^{\circ} \mathrm{C}\right)^{\mathrm{b}}$ & $\mathrm{T}_{\mathrm{p}}\left({ }^{\circ} \mathrm{C}\right)^{\mathrm{b}}$ & $\mathrm{T}_{\mathrm{E}}\left({ }^{\circ} \mathrm{C}\right)^{\mathrm{b}}$ & $\Delta \mathrm{T}\left({ }^{\circ} \mathrm{C}\right)^{\mathrm{b}}$ & $\Delta \mathrm{H}\left(\mathrm{J} \mathrm{g}^{-1}\right)^{\mathrm{b}}$ \\
\hline OD & $61.5^{a} \pm 0.03$ & $68.5^{b} \pm 0.10$ & $78.4 \pm 0.6$ & $16.9 \pm 0.6$ & $9.0^{\mathrm{bc}} \pm 0.3$ \\
\hline SD & $61.3^{\mathrm{b}} \pm 0.04$ & $68.6^{\mathrm{b}} \pm 0.16$ & $79.4 \pm 0.8$ & $18.1 \pm 0.8$ & $9.7^{a} \pm 0.5$ \\
\hline USD & $61.2^{c} \pm 0.05$ & $69.1^{a} \pm 0.10$ & $78.7 \pm 0.2$ & $17.5 \pm 0.3$ & $9.3^{\mathrm{ab}} \pm 0.2$ \\
\hline
\end{tabular}

Values followed by different letters in the same column indicate significant difference at $\mathrm{p}<0.05$ (Fisher); ${ }^{\mathrm{a}} \mathrm{N}$ : native cassava starch; OD, SD, USD: sour cassava starches dried in the oven, in the solar dryer, and under the sun without any protection, respectively; ${ }^{\mathrm{b}} \mathrm{T}_{0}$ : onset temperature; $\mathrm{T}_{\mathrm{p}}$ : peak temperature; $\mathrm{T}_{\mathrm{E}}$ : end temperature; $\Delta \mathrm{T}$ : range temperature; $\Delta \mathrm{H}$ : gelatinization enthalpy. 
Table 5. Sum of ordering values for the group by sensory attributes.

\begin{tabular}{lcccccc}
\hline \multirow{2}{*}{ Groupings } & Attributes & \multicolumn{5}{c}{ Samples $^{1}$} \\
\cline { 3 - 7 } Appearance & Expansion & $64^{\mathrm{d}}$ & $142^{\mathrm{ab}}$ & $126^{\mathrm{b}}$ & $158^{\mathrm{a}}$ & $95^{\mathrm{c}}$ \\
& Yellow color & $67^{\mathrm{c}}$ & $84^{\mathrm{c}}$ & $140^{\mathrm{ab}}$ & $164^{\mathrm{a}}$ & $130^{\mathrm{b}}$ \\
& Rancid & $94^{\mathrm{c}}$ & $103^{\mathrm{bc}}$ & $130^{\mathrm{a}}$ & $137^{\mathrm{a}}$ & $121^{\mathrm{ab}}$ \\
Odor & Sour cassava & $138^{\mathrm{ab}}$ & $149^{\mathrm{a}}$ & $95^{\mathrm{cd}}$ & $83^{\mathrm{d}}$ & $120^{\mathrm{bc}}$ \\
& starch & & & & & \\
\multirow{2}{*}{ Flavor } & Fat & $96^{\mathrm{c}}$ & $109^{\mathrm{bc}}$ & $127^{\mathrm{ab}}$ & $143^{\mathrm{a}}$ & $110^{\mathrm{bc}}$ \\
& Sour cassava & $113^{\mathrm{bc}}$ & $140^{\mathrm{a}}$ & $107^{\mathrm{bc}}$ & $99^{\mathrm{c}}$ & $126^{\mathrm{ab}}$ \\
Texture & starch & & & & & \\
Residual & Hardness & $179^{\mathrm{a}}$ & $91^{\mathrm{c}}$ & $78^{\mathrm{c}}$ & $98^{\mathrm{c}}$ & $139^{\mathrm{b}}$ \\
\hline
\end{tabular}

Values followed by different superscript letters in the same row indicate significant difference at $\mathrm{p}<0.05$ (Fisher); ${ }^{1}$ BSD: biscuit made with dried sour cassava starch in the solar dryer; C1, C2, C3 and C4: biscuits made with commercial sour cassava starch from brands $1,2,3$ and 4 , respectively.

among the configurations of each panel with the group, correcting discrepancies in the panels (Gower, 1975). Principal component analysis (PCA) was employed to characterize the samples in relation to each sensory attribute. Only two PCs were able to explain $69.26 \%$ of total variance, with PC1 and PC2 explaining 45.27 and $23.98 \%$, respectively. The BSD sample had the highest value for hardness and the lowest value for expansion; it had intermediate values for flavor and odor of sour cassava starch. The C3 sample was the opposite. The $\mathrm{C} 1$ and $\mathrm{C} 4$ samples had the highest values for hardness, flavor and odor of sour cassava starch, whereas the $\mathrm{C} 2$ sample had the highest values for yellowness, rancid odor and fat taste.

The Friedman test demonstrated difference between the samples (Table 5). The BSD sample had the lowest expansion value; however, it had more desirable attributes than the other samples. This sample had more intense odor of sour cassava starch, limited rancid odor, lower taste of fat and residual fat, and, with the exception of the $\mathrm{C} 1$ sample, it also had the highest value for flavor of sour cassava starch.

\section{Conclusions}

The solar drying adopted in the present study resulted in reduced time for complete drying without blocking desirable UV-radiation, whilst also minimizing contamination by insect fragments and soil/sand particles. It resulted in a final product with good expansion property.

The biscuits produced with the sample that was dried with this new method had lower expansion levels when compared with the commercial starch samples. However, they presented desirable sensory characteristics, with lower intensities of rancid odor, taste of fat and residual fat flavor, and were also one of the samples with most intense flavor of fermented (sour) cassava starch.

This work is of great importance, as it guaranteed a high-quality product, compared to conventional production. The developed equipment is of low cost, provides a more efficient drying, in addition to using a renewable and clean source of energy, without pollution to the environment.
The results of the present study suggest that further complimentary studies should be performed regarding the fermentation and drying steps. To produce a better product, lactic acid bacteria must be present at high amounts in the inoculum to result in a typical sour cassava starch. Industrial scale production of a high-quality and safe product demands that the solar dryer used in this study should be converted to a real size.

\section{Acknowledgements}

The authors are grateful to the Nutriamidos company for supplying the raw material for this project, to the C-LABMU/ UEPG, and to CAPES and CNPq for financial support.

\section{References}

Almeida, I. B., Lima, M. A. A., \& Souza, L. G. M. (2016). Desenvolvimento de secador solar construído a partir de material reciclável. Holos, 32(4), 197-205. http://dx.doi.org/10.15628/holos.2016.2477.

Alonso-Gomez, L., Niño-López, A. M., Romero-Garzón, A. M., Pineda-Gomez, P., Del Real-Lopez, A., \& Rodriguez-Garcia, M. E. (2016). Physicochemical transformation of cassava starch during fermentation for production of sour starch in Colombia. Stärke, 68(11-12), 1139-1147. http://dx.doi.org/10.1002/star.201600059.

Alvarado, P. M., Grosmaire, L., Dufour, D., Toro, A. G., Sánchez, T., Calle, F., Santander, M. A. M., Ceballos, H., Delarbre, J. L., \& Tran, T. (2013). Combined effect of fermentation, sun-drying and genotype on breadmaking ability of sour cassava starch. Carbohydrate Polymers, 98(1), 1137-1146. http://dx.doi.org/10.1016/j.carbpol.2013.07.012. PMid:23987455.

Aplevicz, K. S., \& Demiate, I. M. (2007). Caracterização de amidos de mandioca nativos e modificados e utilização em produtos panificados. Food Science and Technology (Campinas), 27(3), 478-484. http:// dx.doi.org/10.1590/S0101-20612007000300009.

Aquino, A. C. M. S., Azevedo, M. S., Ribeiro, D. H. B., Costa, A. C. O., \& Amante, E. R. (2015). Validation of HPLC and CE methods for determination of organic acids in sour cassava starch wastewater. Food Chemistry, 172, 725-730. http://dx.doi.org/10.1016/j. foodchem.2014.09.142. PMid:25442614.

Aquino, A. C. M. S., Gervin, V. M., \& Amante, E. R. (2016). Avaliação do processo produtivo de polvilho azedo em indústrias de Santa Catarina. Brazilian Journal of Food Technology, 19(0), 1-8. http:// dx.doi.org/10.1590/1981-6723.5515.

Arduino (2020) Arduino 1.8.13. The open-source Arduino Software (IDE). Arduino Software IDE. Retrived from: https://www.arduino. cc/en/Main/Software

Associação Brasileira de Normas Técnicas - ABNT. (1993). NBR 12995: teste triangular em análise sensorial dos alimentos e bebidas. São Paulo: ABNT.

Beninca, C., Colman, T. A. D., Lacerda, L. G., Carvalho, M. A. S. Fo., Demiate, I. M., Bannach, G., \& Schnitzler, E. (2013). Thermal, rheological, and structural behaviors of natural and modified cassava starch granules, with sodium hypochlorite solutions. Journal of Thermal Analysis and Calorimetry, 111(3), 2217-2222. http://dx.doi. org/10.1007/s10973-012-2592-z.

Bhattacharjya, B., Dutta, H., Patwari, K., \& Mahanta, C. L. (2015). Properties of annealed jackfruit (Artocarpus Heterophyllus Lam.) seed starch. Acta Alimentaria, 44(4), 501-510. http://dx.doi. org/10.1556/066.2015.44.0021. 
Brasil. Ministério da Saúde. Agência Nacional de Vigilância Sanitária. (2005, Setembro 23). Resolução RDC n 263, de 22 de setembro de 2005. Diário Oficial [da] República Federativa do Brasil, seção 1.

Cereda, M. P., \& Bonassi, I. A. (1985). Avaliação da qualidade da fécula fermentada comercial de mandioca (polvilho azedo). Ácidos orgânicos e absorção de água. Revista Brasileira de Mandioca, 3(2), 21-30.

Christensen, Z. T., Ogden, L. V., Dunn, M. L., \& Eggett, D. L. (2006). Multiple comparison procedures for analysis of ranked data. Journal of Food Science, 71(2), S132-S143. http://dx.doi. org/10.1111/j.1365-2621.2006.tb08916.x.

Demiate, I. M., Sanger, S. A., Vogler, Z., Cereda, M. P., \& Wosiacki, G. (1997a). Características de qualidade de amostras de polvilho azedo produzido ou comercializado no Estado do Paraná. Arquivos de Biologia e Tecnologia, 40(2), 321-330.

Demiate, I. M., Souza, T. O., Pugsley, S., Cereda, M. P., \& Wosiacki, G. (1997b). Características de qualidade de amostras de polvilho azedo. Parte 2 - Santa Catarina. Agropecuária Catarinense, 10(4), 51-56.

Demiate, I. M., Souza, T. O., Nogueira, A., Wosiacki, G., \& Cereda, M. P. (1998). Características de qualidade de polvilho azedo Parte 3 - Rio Grande do Sul. Publicatio UEPG Ciências Exatas e da Terra, 4(1), 97-112.

Demiate, I. M., Barana, A. C., Cereda, M. P., \& Wosiacki, G. (1999). Organic acid profile of commercial sour cassava starch. Food Science and Technology (Campinas), 19(1), 131-135. http://dx.doi. org/10.1590/S0101-20611999000100024.

Demiate, I. M., Dupuy, N., Huvenne, J. P., Cereda, M. P., \& Wosiacki, G. (2000). Relationship between baking behavior of modified cassava starches and starch chemical structure determined by FTIR spectroscopy. Carbohydrate Polymers, 42(2), 149-158. http://dx.doi. org/10.1016/S0144-8617(99)00152-6.

Demiate, I. M., Wosiacki, G., Cereda, M. P., \& Mestres, C. (2005). Viscographic characteristics of chemically modified cassava starches assessed by RVA. Publicatio UEPG Ciências Exatas da Terra Agrárias e Engenharias, 11(1), 7-17. http://dx.doi.org/10.5212/publicatio. v11i01.840.

Demiate, I. M., Figueroa, A. M., Zortéa Guidolin, M. E. B., Santos, T. P. R., Yangcheng, H., Chang, F., \& Jane, J. L. (2016). Physicochemical characterization of starches from dry beans cultivated in Brazil. Food Hydrocolloids, 61, 812-820. http://dx.doi.org/10.1016/j. foodhyd.2016.07.014.

Díaz, A., Dini, C., Viña, S. Z., \& García, M. A. (2018). Technological properties of sour cassava starches: Effect of fermentation and drying processes. Lebensmittel-Wissenschaft + Technologie, 93, 116-123. http://dx.doi.org/10.1016/j.lwt.2018.03.029.

Eltawil, M. A., Azam, M. M., \& Alghannam, A. O. (2018). Energy analysis of hybrid solar tunnel dryer with PV system and solar collector for drying mint (MenthaViridis). Journal of Cleaner Production, 181, 352-364. http://dx.doi.org/10.1016/j.jclepro.2018.01.229.

Garcia, M. C., Franco, C. M. L., Júnior, M. S. S., \& Caliari, M. (2016). Structural characteristics and gelatinization properties of sour cassava starch. Journal of Thermal Analysis and Calorimetry, 123(2), 919-926. http://dx.doi.org/10.1007/s10973-015-4990-5.

García-Valladares, O., Ortiz, N. M., Pilatowsky, I., \& Menchaca, A. C. (2020). Solar thermal drying plant for agricultural products. Part 1: Direct air heating system. Renewable Energy, 148, 1302-1320. http://dx.doi.org/10.1016/j.renene.2019.10.069.

Gower, J. C. (1975). Generalized procustes analysis. Psychometrika, 40(1), 33-51. http://dx.doi.org/10.1007/BF02291478.

Instituto Adolfo Lutz - IAL. (2008). Métodos físico-químicos para análise de alimentos (4. ed.). São Paulo: IAL.
Jane, J. L., Chen, Y. Y., Lee, L. F., Mcpherson, A. E., Wong, K. S., Radosavljevic, M., \& Kasemsuwan, T. (1999). Effects of amylopectin branch chain length and amylose content on the gelatinization and pasting properties of starch. Cereal Chemistry, 76(5), 629-637. http:// dx.doi.org/10.1094/CCHEM.1999.76.5.629.

Lawal, O. S., Adebowale, K. O., Ogunsanwo, B. M., Barba, L. L., \& Ilo, N. S. (2005). Oxidized and acid thinned starch derivatives of hybrid maize: Functional characteristics, wide-angle X-ray diffractometry and thermal properties. International Journal of Biological Macromolecules, 35(1-2), 71-79. http://dx.doi.org/10.1016/j.ijbiomac.2004.12.004. PMid:15769518.

Maeda, K. C., \& Cereda, M. P. (2001). Avaliação de duas metodologias de expansão ao forno do polvilho azedo. Food Science and Technology (Campinas), 21(2), 139-143. http://dx.doi.org/10.1590/S010120612001000200003.

Matsuguma, L. S., Lacerda, L. G., Schnitzler, E., Carvalho Filho, M. A. S., Franco, C. M. L., \& Demiate, I. M. (2009). Characterization of native and oxidized starches of two varieties of Peruvian carrot (Arracacia xanthorrhiza B.) from two production areas of Paraná state, Brazil. Brazilian Archives of Biology and Technology, 52(3), 701-713. http://dx.doi.org/10.1590/S1516-89132009000300022.

Meng, L., Zhang, W., Wu, Z., Hui, A., Gao, H., Chen, P., \& He, Y. (2018). Effect of pressure-soaking treatments on texture and retrogradation properties of black rice. Lebensmittel-Wissenschaft + Technologie, 93, 485-490. http://dx.doi.org/10.1016/j.lwt.2018.03.079.

Mestres, C., \& Rouau, X. (1997). Influence of natural fermentation and drying conditions on the physicochemical characteristics of cassava starch. Journal of the Science of Food and Agriculture, 74(2), 147-155. http://dx.doi.org/10.1002/(SICI)1097-0010(199706)74:2<147::AIDJSFA781>3.0.CO;2-J.

Mestres, C., Boungou, O., Akissoë, N., \& Zakhia, N. (2000). Comparison of the expansion ability of fermented maize flour and cassava starch during baking. Journal of the Science of Food and Agriculture, 80(6), 665-672. https://doi.org/10.1002/(SICI)10970010(20000501)80:6<665::AID-JSFA585>3.0.CO;2-K.

Milczarek, R. R., Avena-Mascareno, R., Alonzo, J., \& Fichot, M. I. (2016). Improving the sun drying of apricots (Prunus armeniaca) with photo-selective dryer cabinet materials. Journal of Food Science, 81(10), E2466-E2475. http://dx.doi.org/10.1111/1750-3841.13444. PMid:27648527.

Moskowitz, H. R. (1983). Product testing and sensory evaluation of foods - marketing and R\&D approaches. Westport: Food and Nutrition Press, Inc.

Nara, S., \& Komiya, T. (1983). Studies on the relationship between water-satured state and crystallinity by the diffraction method for moistened potato starch. Stärke, 35(12), 407-410. http://dx.doi. org/10.1002/star.19830351202.

Oliveira, D. C. (2016). Efeito da secagem solar e em estufa convectiva sobre as características físico-químicas e reológicas do polvilho azedo (Ph.D. thesis). Universidade Federal de Santa Catarina, Florianópolis.

Pereira, J. M., Aquino, A. C. M. S., Oliveira, D. C., Rocha, G., Francisco, A., Barreto, P. L. M., \& Amante, E. R. (2016). Characteristics of cassava starch fermentation wastewater based on structural degradation of starch granules. Ciência Rural, 46(4), 732-738. http://dx.doi. org/10.1590/0103-8478cr20150632.

Qi, Q., Hong, Y., Zhang, Y., Gu, Z., Cheng, L., Li, Z., \& Li, C. (2020). Combinatorial effect of fermentation and drying on the relationship between the structure and expansion properties of tapioca starch and potato starch. International Journal of Biological Macromolecules, 145, 965-973. http://dx.doi.org/10.1016/j.ijbiomac.2019.09.187. PMid:31614157. 
Richter, V. B., Almeida, T. C. A., Prudencio, S. H., \& Benassi, M. T. (2010). Proposing a ranking descriptive sensory method. Food Quality and Preference, 21(6), 611-620. http://dx.doi.org/10.1016/j. foodqual.2010.03.011.

Schoch, J. C. (1964). Iodimetric determination of amylose. Potentiometric titration Standard methods. In R. L. Whistler (Ed.), Methods in carbohydrate chemistry (cap. 37, pp. 157-160). London: Academic Press.

Sharma, A., Chen, C. R., \& Vu Lan, N. (2009). Solar-energy drying systems: a review. Renewable \& Sustainable Energy Reviews, 13(6-7), 1185-1210. http://dx.doi.org/10.1016/j.rser.2008.08.015.

Shirose, I., \& Mori, E. E. M. (1984). Aplicação da análise seqüencial à seleção de provadores pelo teste triangular. Coletânea do ITAL, $14,39-55$.
Silveira, I. A., Carvalho, E. P., Padua, I. P. M., \& Dionizio, L. F. (2003). Isolamento e caracterização da microbiota ácido lática envolvida no processo fermentativo para produção de polvilho azedo - parte II. Pro Homine, 2(2), 7-15.

Sumardiono, S., Jos, B., Firmanssyah, D., Hidayatunajah, R., \& Pudjihastuti, I. (2018). Modification of cassava starch using lactic acid hydrolysis in the rotary-UV dryer to improve physichocemical properties. MATEC Web of Conferences, 156, 1-8. https://doi.org/10.1051/ matecconf/201815601018.

Vanier, N. L., Zavareze, E. R., Pinto, V. Z., Klein, B., Botelho, F. T., Dias, A. R. G., \& Elias, M. C. (2012). Physicochemical, crystallinity, pasting and morphological properties of bean starch oxidised by different concentrations of sodium hypochlorite. Food Chemistry, 131(4), 1255-1262. http://dx.doi.org/10.1016/j.foodchem.2011.09.114. 